\title{
Evaluation of using solar ammonia absorption cooling system for major cities of the Middle East
}

\author{
Tohid Adibi
}

Department of mechanical engineering, University of Bonab, Bonab 5551761167, Iran

Corresponding Author Email: Tohidadibi@bonabu.ac.ir

https://doi.org/10.18280/ijht.360309

Received: 7 November 2017

Accepted: 3 September 2018

\section{Keywords:}

Middle East, solar cooling, HVAC, EES, cooling load

\begin{abstract}
Solar energy is an important source of renewable energy. In this paper, renewable energy is used to cooling purpose in the Middle East. The cooling load is calculated for major cities of the Middle East. An ammonia absorption refrigeration cycle (AARC) is used for cooling purpose. Solar energy is used as the source of high temperature. Codes are written in EES software to analysis the solar cooling cycle. In this analysis, temperature, enthalpy, and other thermodynamic properties are obtained in different cases. Weather properties information such as winter and summer design temperatures of these cities are obtained from HVAC handbooks. The variation of temperature and cooling capacity in different months and different hours of a day is calculated and is shown in different figures. Cooling ability of solar cooling system varies in the different month and different hours. Furthermore, the influence of the efficiency of heat exchanger of solar cooling system on the coefficient of performance of cycle and the cooling capacity is investigated. In this paper, different climates with summer design dry bulb between $32^{\circ} \mathrm{C}$ and $47^{\circ} \mathrm{C}$ and solar heat gain between $840 \mathrm{w} / \mathrm{m}^{2}$ and $890 \mathrm{w} / \mathrm{m}^{2}$ are considered.
\end{abstract}

\section{INTRODUCTION}

With concerns of energy lacks and air pollution, solar energy is known as one of the most beneficial energies for its rewards of being renewable and clean. The ammonia-H2O solar absorption cooling system (SACS) is a good prospect since it can produce a higher coefficient of performance (COP) under lower heat source temperature conditions. The majority of researches on SACS have focused on as follows. Zhang et al. [1] presented a multi-stage heat storage system using phase change materials with different melting points into the heat pump solar absorption cooling system which suggested by their earlier research work [2]. By meteorological data for the city of Nanjing, the performance of the new system with a chilling capacity of $10 \mathrm{~kW}$ is analyzed. Tiwari et al. [3] wrote the computer code in MATLAB 9.0 which is interfaced with Refprop 9.0 in order to improve a thermodynamic model of solar driven organic Rankine cycle. An innovative glazed reverse absorber conventional composite parabolic concentrator integrated with recovered organic Rankine cycle.

Paradis et al. [4] presented a genuine two-dimensional transient numerical model to estimate the temperature field and the dependent electrical performances of different solar absorber plates. It can readily be adapted for solar thermal absorber plates, standard PV plates or thermally enhanced PV plates that can be used in PV/T solar collectors. The model can also be joined with the appropriate heat exchanger equations to simulate a complete solar collector. Lizarte et al [5] led experimental trials on a new solar-driven, directly air-cooled, single effect, $4.5 \mathrm{~kW}-\mathrm{LiBr} / \mathrm{H} 2 \mathrm{O}$ absorption cooler prototype. The aim was to air-condition a 40-m2 room located in Madrid. The solar capability contained whiten a vacuum flat-plate collector field, with a total aperture area of $42.2 \mathrm{~m} 2$, a $25-\mathrm{kW}$ external plate heat exchanger and a $1.5-\mathrm{m} 3$ storage tank. AbuEin et al. [6] provided a full thermodynamic analysis of a
$10 \mathrm{~kW}$ solar absorption chilling system using ammonia-water combinations as a working medium. This analysis contains both first law and second law of thermodynamics. The coefficient of performance (COP), exergetic coefficient of performance $(\mathrm{ECOP})$ and the exergy losses $(\Delta \mathrm{E})$ through each section of the system at different working conditions are achieved.

Ursula Eicker and Dirk Pietruschka [7] worked on solar thermal absorption coolers. A complete simulation model was established for absorption chilling systems, combined with a stratified storing tank, steady-state or dynamic collector model and hourly resolved building loads. The model was validated with experimental data from several solar cooling plants. Adibi et al [8] investigated effect of intercooler on the network and efficiency of Brayton cycle (BCE). In this research, different states such as ideal Brayton cycle (BC) with intercooler and with or without regenerator and also real BCs are considered. In all of the cases the effect of parameters like Intercooler output temperature, intercooler internal pressure, on the compressor consumed work (CCW) and on cycle efficiency is investigated and the optimal pressure (OP) and temperature in each state are determined. Adibi et al. [8] simulated another thermodynamics cycle in EES software and found the optimum states. Mesmoudi et al. [9] designed the greenhouse, as well as the cover material properties in particular, may strongly impact the greenhouse energy. To study the effect of these parameters, three typical unheated greenhouses equipped with rows of canopy were considered. Experiments were launched to establish the boundary conditions and validate the model. Bataineh and Taamneh [10] investigated the performance of standalone solar Stirling dish system used to electrify rural houses. The yearly performance which depends on location is simulated using software developed by The National Renewable Energy Laboratory's SAM (Solar Advisor Model). Direct normal insolation, 
ambient temperature, density of air (altitude), sun elevation angle, and the wind speed are included in the simulation model.

Yayun et al. [11] simulated and analyzed the flow field characteristics and the random features of particle trajectories inside a hydrocyclone based on computational fluid dynamics.

Mustafa [12] performed a theoretical model to study the effect of magnetic field on transient free convection flow of an electrically conducting fluid past an accelerated vertical plate with periodic temperature.

\section{DESCRIPTION OF USED SYSTEM}

The ammonia absorption refrigeration cycle (AARC) is shown in Figure 1. The solar is the high-temperature source for this cycle in this research. This AARC is used for cooling purpose in Middle East cities. In this cycle, high pressure Liquid ammonia pass the expansion valve and its pressure fall down and its state become the composite of liquid and gas. This composite enters evaporator and absorbs heat from cold place and it becomes ammonia vapor in low pressure. Low pressure ammonia vapor goes to absorber and it is absorbed to water. The new liquid passes the pump and its pressure goes up. This strong ammonia solution in high pressure obtains heat in heat exchanger and enters generator. This liquid absorbs heat from solar energy and high pressure ammonia vapor and weak ammonia solution exit from generator. The weak ammonia solution goes to the heat exchanger and the high pressure ammonia vapor goes to the condenser. In the condenser, heat transfer from high pressure ammonia vapor to the surrounding and the high pressure ammonia vapor converts liquid.

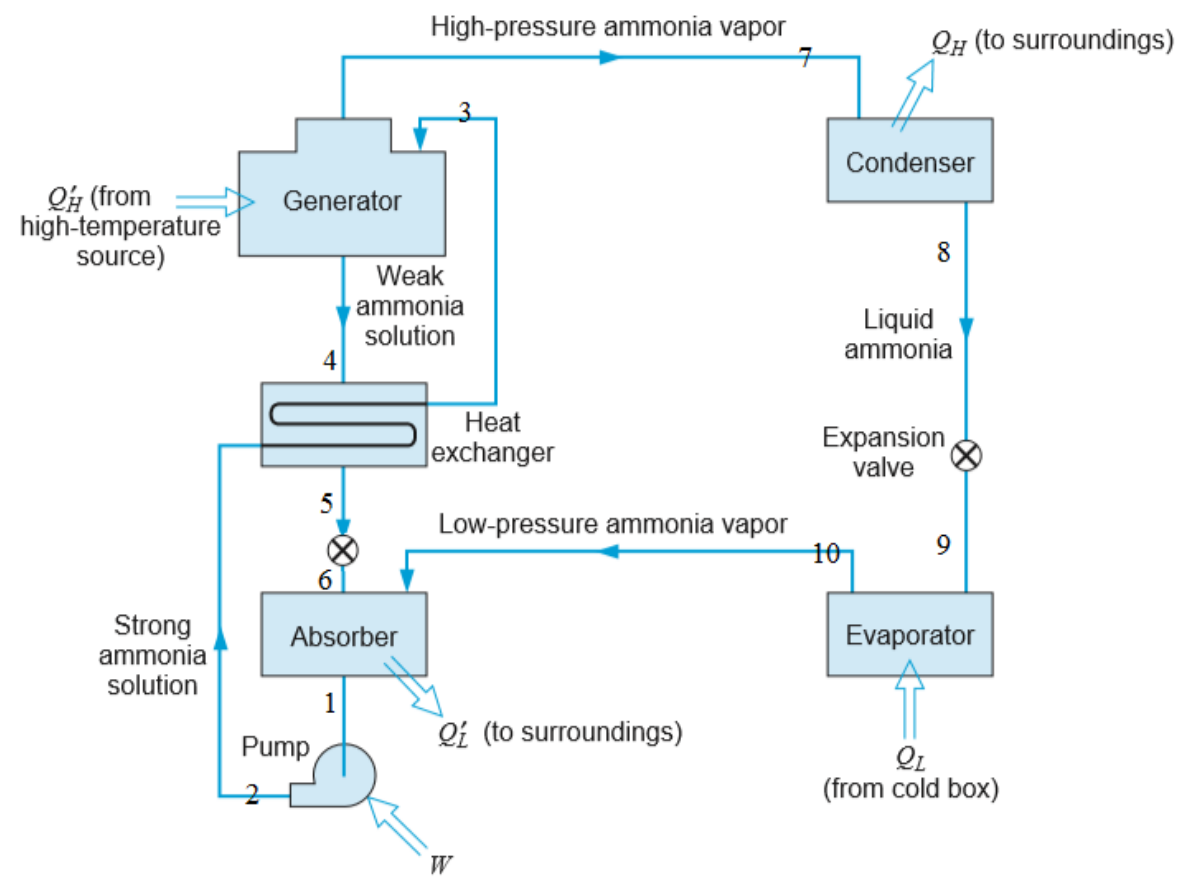

Figure 1. The ammonia absorption refrigeration cycle [11]

\section{THERMODYNAMIC ANALYSIS}

The rate of heat transfer from condenser to ambient is obtained by

$$
Q_{\text {Condenser }}=\dot{m}_{7} \times\left(h_{7}-h_{8}\right)
$$

where " $\dot{m}$ " is the mass flow rate, and " $h$ " is the enthalpy. For expansion valve, one has

$$
h_{8}=h_{9}
$$

The rate of heat removal from evaporator is expressed as

$$
Q_{\text {Evaporator }}=\dot{m}_{10}\left(h_{10}-h_{9}\right)
$$

The rate of heat transfer from condenser to ambient is found by

$Q_{\text {Absorber }}=\dot{m}_{10} h_{10}+\dot{m}_{6} h_{6}-\dot{m}_{1} h_{1}$

The input power for pump is obtained by

$W_{\text {Pump }}=\dot{m}_{1}\left(h_{2}-h_{1}\right)=\dot{m}_{1} v_{1}\left(p_{2}-p_{1}\right)$

where " $v$ " is the specific volume, and " $p$ " is the pressure. For heat exchanger, one has

$$
\dot{m}_{2} h_{2}+\dot{m}_{4} h_{4}=\dot{m}_{3} h_{3}+\dot{m}_{5} h_{5}
$$

The rate of heat transfer in generator is found by

$$
Q_{\text {Generator }}=\dot{m}_{4} h_{4}+\dot{m}_{7} h_{7}-\dot{m}_{3} h_{3}
$$


Solar energy is used as a high-temperature source to prepare the necessary heat for the generator. Solar cells are absorbed solar energy. So the rate of absorbed energy in generator can be calculated from

$$
Q_{\text {Generator }}=A \times S H G \times \eta_{\text {Generator }}
$$

where " $\mathrm{A}$ " is the solar cells area, "SHG" is solar energy per area, and " $\eta_{\text {Generator }}$ " is the efficiency of generator and is found by

$$
\eta_{\text {Generator }}=0.67-5.52 \times\left(\mathrm{T}_{s}-\mathrm{T}_{a}\right) / S H G
$$

where " $\mathrm{T}_{\mathrm{s}}$ " is the temperature of solar cell and " $\mathrm{T}_{\mathrm{a}}$ " is the temperature of ambient.

According to continuity, one takes

$$
\begin{aligned}
& \dot{m}_{1}=\dot{m}_{6}+\dot{m}_{10}, \\
& \dot{m}_{3}=\dot{m}_{4}+\dot{m}_{7}, \\
& \dot{m}_{1} x_{1}=\dot{m}_{6} x_{6}+\dot{m}_{10} \mathrm{x}_{10}, \\
& \dot{m}_{3} x_{3}=\dot{m}_{4} x_{4}+\dot{m}_{7} \mathrm{x}_{7} .
\end{aligned}
$$

where " $x$ " is the ammonia ratio in mixture and is defined as

$x=\frac{m_{\text {ammonia }}}{m_{\text {ammonia }}+m_{\text {water }}}$

The coefficient of performance is obtained by

$$
C O P=\frac{Q_{\text {Evaporator }}}{Q_{\text {absorber }}+W_{p}}
$$

In the following, calculation of cooling load for a building is explained. The cooling load from walls, floors, and roofs is obtained by

$\mathrm{Q}=\mathrm{AU} \Delta \mathrm{T}_{\mathrm{e}}$

where " $\mathrm{A}$ " is the area, " $\mathrm{U}$ " is the total heat transfer coefficient, and " $\Delta \mathrm{T}_{\mathrm{e}}$ " is the effective temperature difference. The cooling load for windows is calculated from

$Q=f_{1} f_{2} f_{3} f_{4} f_{5} f_{6} \times A \times S H G$

where $f_{1}$ to $f_{6}$ are the correction coefficients, " $A$ " is the area, and "SHG" is the solar heat gains. The cooling load is gained from

$Q_{s}=1010(\mathrm{~kJ} / \mathrm{kg} \cdot \mathrm{K}) \dot{m}_{a}\left(T_{i}-T_{o}\right)$,

$Q_{L}=2.457 \times 10^{6}(\mathrm{~kJ} / \mathrm{kg}) \dot{m}_{a}\left(\omega_{i}-\omega_{o}\right)$

where " $\mathrm{Q}_{\mathrm{s}}$ ", " $\mathrm{Q}_{\mathrm{L}}$ " are the sensitive and latent loads, " $\dot{m}_{a}$ " is the mass flow, " $\mathrm{T}_{\mathrm{i}}$ ", " $\mathrm{T}_{\mathrm{o}}$ " are the inside and outside temperature," $\omega_{i}, \omega_{o}$ " are the internal and external humidity. To obtain the total cooling load, one must consider the cooling loads of people and instrument such as oven.

\section{PERFORMANCE ANALYSIS}

In this research, solar absorber system is used to prepare cooling load of a building. In each simulation, equation 1 to 15 and thermodynamics tables are used to obtain the unknown variations in each point. For solving, a code is written in EES software. The results of first simulations are displayed in table 1. In this simulation, the input variations are

$T_{s}=320 K, T_{a}=310 K, S H G=0.58 \frac{\mathrm{kW}}{\mathrm{m}^{2}}$,

$Q_{\text {evaponator }}=20 \mathrm{~kW}, \eta_{\text {Heat Exchanger }}=0.8$

where "Ts" is the solar surface temperature, and "Ta" is the ambient temperature.

Where " $h$ " is enthalpy, " $m$ " is mass flow rate, " $p$ " is pressure, "qu" is quality, "s" is entropy, " $T$ " is temperature, " $u$ " is internal energy, " $v$ " is specific volume, and " $x$ " is the ammonia ratio in mixture.In this part, the influence of independent parameters on solar cycle performance is surveyed. In this paper, the capital of the Middle East is studied for cooling purpose. So in the first step, one needs this cities heat, ventilation and air condition (HVAC) information. This data is shown in Table 2 .In this paper, ASHREA handbook[12] is used for HVAC information. Summer and winter design dry bulb temperature are the important information to calculate cooling and heating loads. This information is shown in Figure 2. Kuwait has the hottest and Ankara has the coolest weather in the summer. Ankara is the coldest and Masqat is the warmest in the winter. The SHG is important to calculate the cooling load. When AARC is used as cooling system, it is important to calculate the cooling capacity of the cooling system. The SHG is shown for different cities in Figure 3. Abu Dhabi has the highest and Ankara has the lowest SHG.

The solar energy is not constant during the day and during the year. Solar heat gains alters during the day. For example, this variation is shown for Cairo in different hour in Figure 4 and is displayed for Tehran in different month. It is obvious that SHG is maximum in the middle of the day and in June. The higher SHG means the higher cooling capacity.

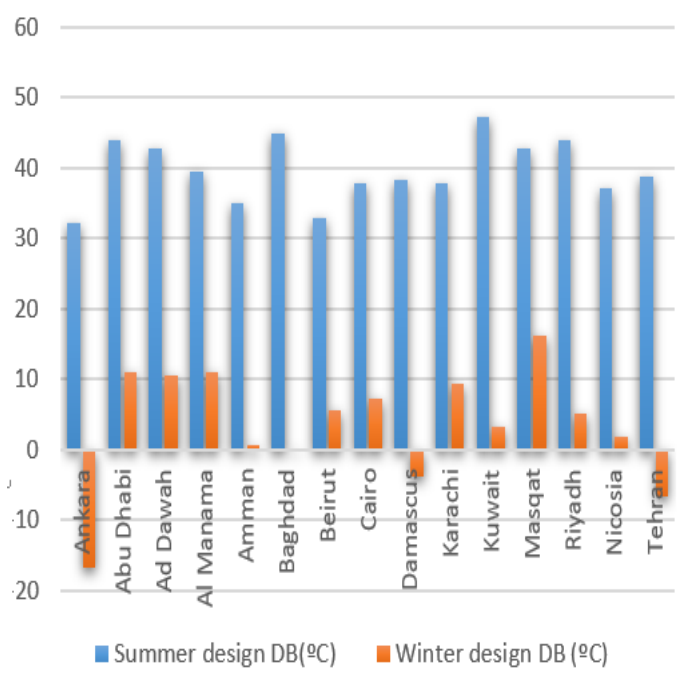

Figure 2. Summer and winter design dry bulb temperature for different cities 


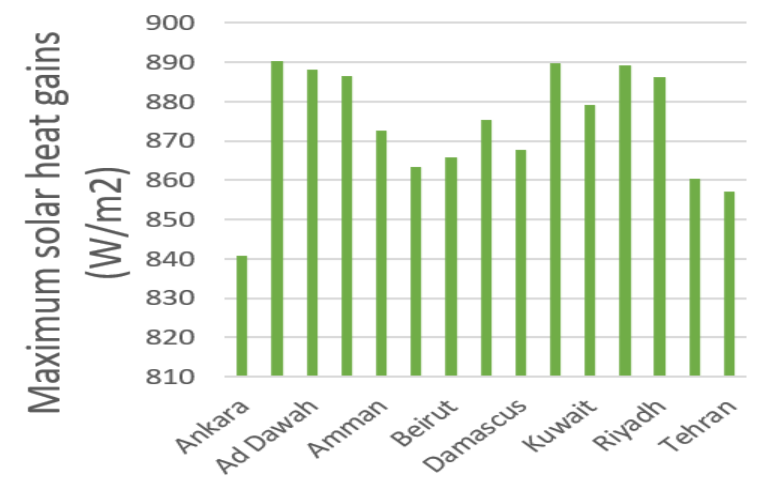

Figure 3. Maximum heat gains for different citie

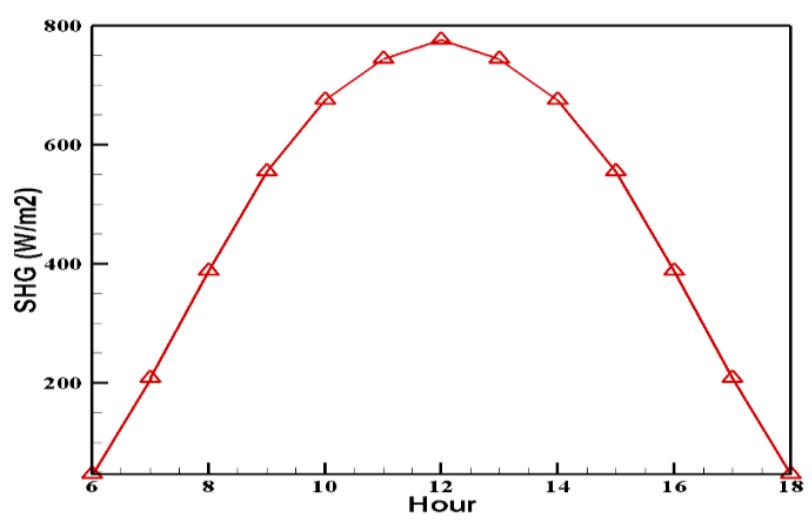

Figure 4. SHG for Cairo in different hour in June-23th

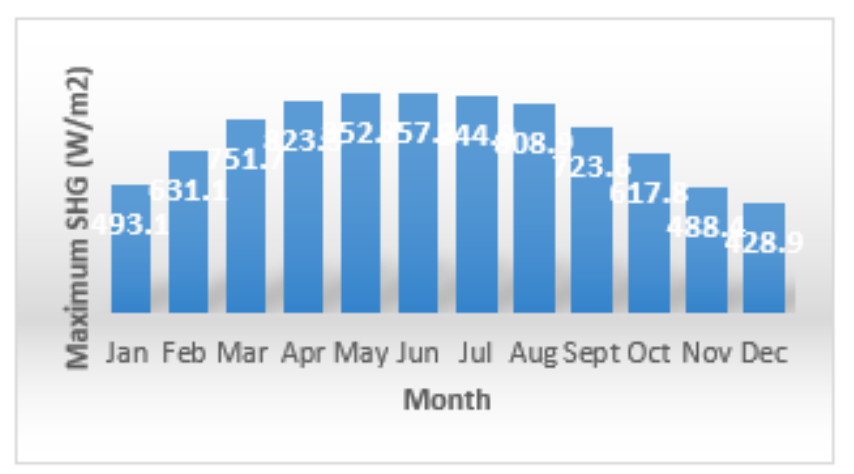

Figure 5. Maximum SHG for Tehran in different months

The temperature of these cities is changed during the day and the year. For example, this variation is shown in Figure 6 for Cairo in different hours and is displayed in different months for Kuwait in Figure 7. Figure 6 has a maximum such as Figure 4. The place of maximum is not equal for these figures. It is a 3 hours gap between two maximums. Also, Figure 5 and Figure 7 are similar. The higher ambient temperature means the higher cooling load. These figures show that higher capacity of cooling is near the higher cooling load. This is a good result. This result shows that AARC is the suitable system for cooling purpose.

According to equation (9), the efficiency of the solar regenerator depends on solar surface and ambient temperatures and SHG. The efficiency of generator versus temperature difference and SHG are displayed in Figure 8 and Figure 9. Figure 8 shows that the efficiency of generator strongly depends on difference between solar surface and ambient temperature. The efficiency decreases sharply when this difference increases. Figure 9 demonstrates that the efficiency of generator increases when SHG rises.

One of the important parameters in solar absorber cooling system is the capacity of cooling in evaporator. To show the influence of SHG and ambient temperature on this parameter, cooling capacity is calculated in varies SHG and ambient temperature and results are depicted in Figure 10 and Figure 11. Cooling capability linearly rises when SHG increases. Cooling capacity decreases while ambient temperature escalates.

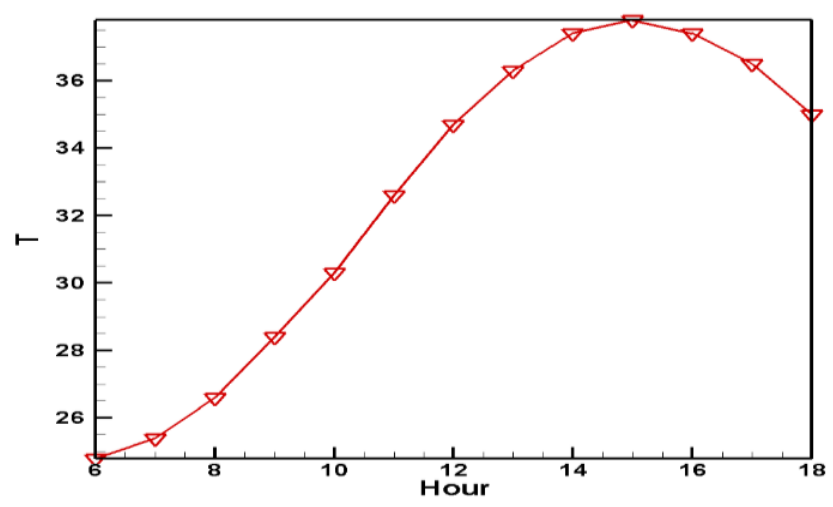

Figure 6. Dry bulb temperature for Cairo in different hour in June-23th

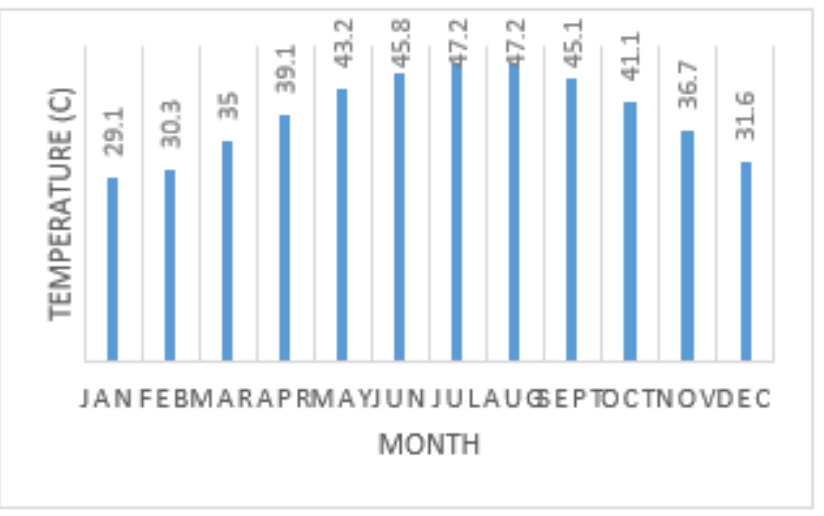

Figure 7. Maximum dry bulb temperature for Kuwait in different months

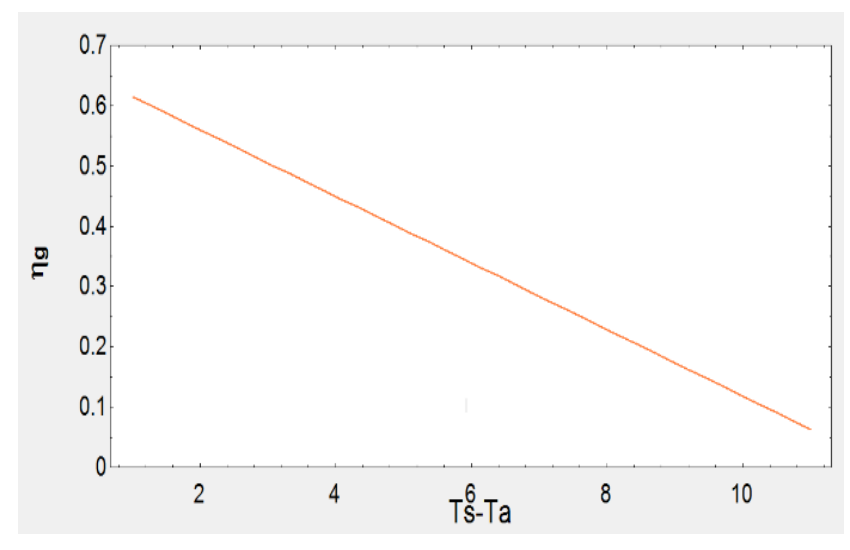

Figure 8. The efficiency of generator versus Ts-Ta 
Table 1. Information in each point

\begin{tabular}{cccccccccc}
\hline point & $\mathrm{h}(\mathrm{kJ} / \mathrm{kg})$ & $\mathrm{m}(\mathrm{kg} / \mathrm{s})$ & $\mathrm{p}(\mathrm{bar})$ & $\mathrm{qu}$ & $\mathrm{s}(\mathrm{kJ} / \mathrm{kg} . \mathrm{K})$ & $\mathrm{T}(\mathrm{K})$ & $\mathrm{u}(\mathrm{kJ} / \mathrm{kg})$ & $\mathrm{v}\left(\mathrm{m}^{3} / \mathrm{kg}\right)$ & $\mathrm{x}$ \\
\hline 1 & 77.81 & 0.1428 & 5.372 & 0 & 0.8374 & 340 & 77.17 & 0.001187 & 0.36068 \\
2 & 78.86 & 0.1428 & 14.25 & 0 & 0.8374 & 340.1 & 77.17 & 0.001187 & 0.36068 \\
3 & 266.5 & 0.1428 & 14.25 & 0.006493 & 1.358 & 379.5 & 263.6 & 0.002029 & 0.36068 \\
4 & 381.2 & 0.1247 & 14.25 & 0 & 1.602 & 400 & 379.5 & 0.001239 & 0.26768 \\
5 & 166.3 & 0.1247 & 14.25 & 0 & 1.03 & 352.1 & 164.7 & 0.001157 & 0.26768 \\
6 & 166.3 & 0.1247 & 5.372 & 0 & 1.033 & 352.2 & 165.7 & 0.001158 & 0.26768 \\
7 & 1325 & 0.01814 & 14.25 & 1 & 4.302 & 320 & 1188 & 0.09588 & 1 \\
8 & 175.4 & 0.01814 & 14.25 & 0 & 0.6076 & 310 & 172.9 & 0.001717 & 1 \\
9 & 175.4 & 0.01814 & 5.372 & 0.118 & 0.6376 & 279.3 & 159.8 & 0.02897 & 1 \\
10 & 1278 & 0.01814 & 5.372 & 1 & 4.584 & 280 & 1152 & 0.2437 & 1 \\
\hline
\end{tabular}

Table 2. The HVAC information of some important cities in The Middle East

\begin{tabular}{|c|c|c|c|c|c|c|}
\hline & latitude & longitude & Elevation (m) & $\begin{array}{c}\text { Summer design DB } \\
\left({ }^{\circ} \mathrm{C}\right)\end{array}$ & $\begin{array}{c}\text { Winter design DB } \\
\left({ }^{\circ} \mathrm{C}\right)\end{array}$ & $\begin{array}{l}\text { Maximum solar heat } \\
\text { gains }\left(\mathrm{W} / \mathrm{m}^{2}\right)\end{array}$ \\
\hline Ankara & 40.1 & -33.0 & 948.8 & 32.2 & -16.7 & 840.9 \\
\hline Abu Dhabi & 24.4 & -54.7 & 26.8 & 43.9 & 11.1 & 890.4 \\
\hline Ad Dawah & 25.3 & -51.6 & 9.8 & 42.8 & 10.6 & 888.0 \\
\hline Al Manama & 26.3 & -50.7 & 1.8 & 39.4 & 11.1 & 886.4 \\
\hline Amman & 32.0 & -36.0 & 773.0 & 35.0 & 0.6 & 872.7 \\
\hline Baghdad & 33.3 & -44.6 & 33.8 & 45.0 & 0 & 863.3 \\
\hline Beirut & 33.9 & -35.5 & 33.8 & 32.8 & 5.6 & 865.8 \\
\hline Cairo & 30.1 & -31.4 & 73.8 & 37.8 & 7.2 & 875.4 \\
\hline Damascus & 33.4 & -36.5 & 604.7 & 38.3 & -3.9 & 867.8 \\
\hline Karachi & 24.8 & -67.0 & 4.0 & 37.8 & 9.4 & 889.7 \\
\hline Kuwait & 29.2 & -48.0 & 54.9 & 47.2 & 3.3 & 879.2 \\
\hline Masqat & 23.6 & -58.3 & 14.9 & 42.8 & 16.1 & 889.3 \\
\hline Riyadh & 24.7 & -46.7 & 611.7 & 43.9 & 5.0 & 886.3 \\
\hline Nicosia & 35.2 & -33.3 & 224.0 & 37.2 & 1.7 & 860.4 \\
\hline Tehran & 35.7 & -51.4 & 1219.8 & 38.9 & -6.7 & 857.2 \\
\hline
\end{tabular}

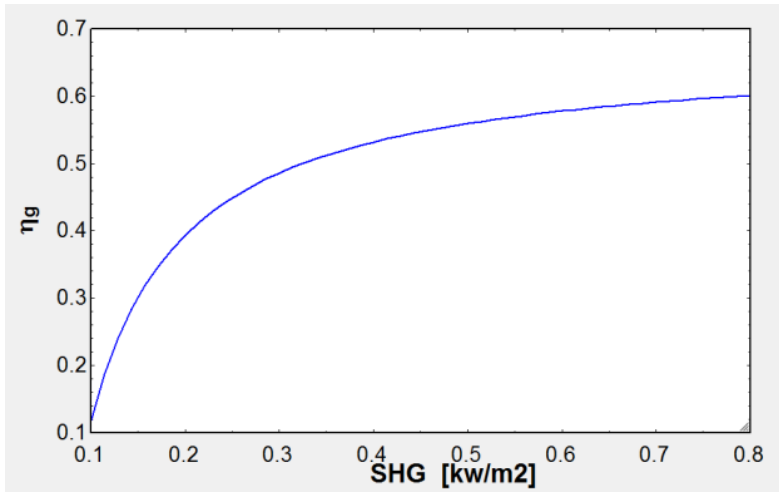

Figure 9. The efficiency of generator versus SHG

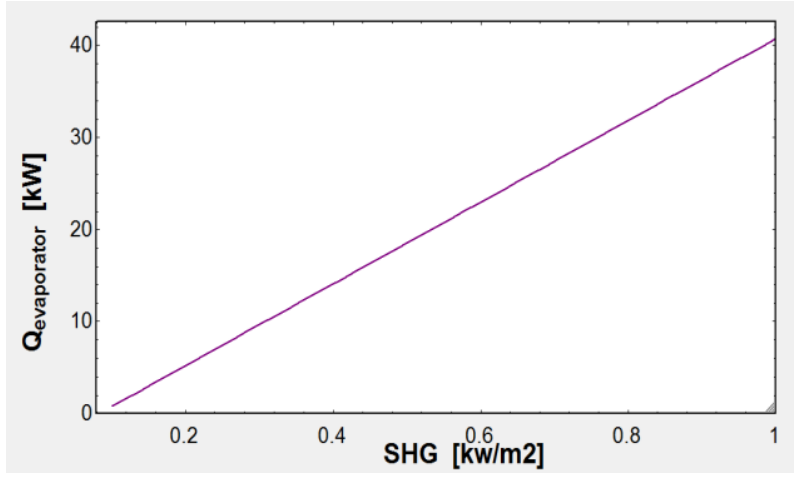

Figure 10. Cooling capacity in evaporator versus SHG

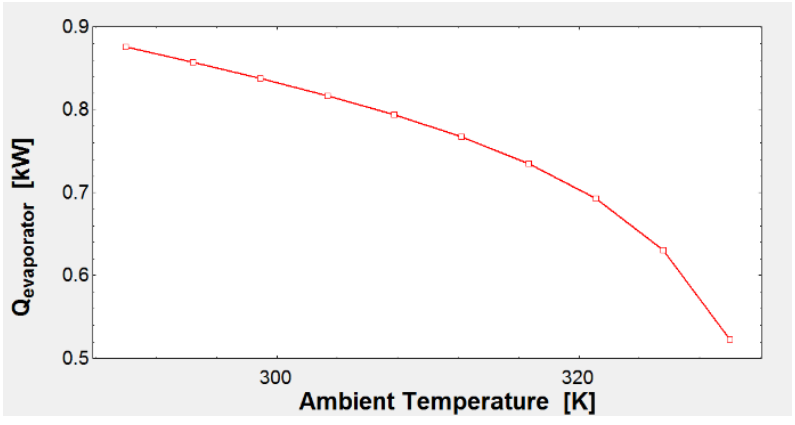

Figure 11. Cooling capacity in evaporator versus ambient Temperature in $\mathrm{SHG}=0.1 \mathrm{~kW} / \mathrm{m}^{2}$

In Figure 12, the effects of SHG and ambient temperature are considered at the same time then cooling capacity is displayed versus time. Figure 10 is an ascending chart and Figure 11 is a descending chart. But Figure 12 has a maximum in the noon. This results are good too because the maximum cooling capacity is in the noon and maximum cooling load occurs at the same time.

To accurate analysis, an apartment in different cities is considered and its cooling and heating load are calculated. Results are shown in Table 3 and Figure 13. The floor area of this apartment is $10 \mathrm{~m}^{2}$. This apartment has windows in north and south. The area of these windows is $9 \mathrm{~m}^{2}$ and $12 \mathrm{~m}^{2}$. Kuwait has the maximum cooling load and Ankara has the minimum cooling load between these cities. Ankara has the maximum heating load and Masqat has the minimum heating load. The cooling and the heating loads are shown in Figure 13 and Figure 14 for July and January in different hours of the 
day. These figures demonstrate that the cooling and heating load depend on the time of the day.

In this part, the effect of heat exchanger efficiency is surveyed. For this reason, the efficiency of heat exchanger is altered from $50 \%$ to $100 \%$. Then COP and cooling capacity are calculated in each state. Consequences are expressed in Figure 16 and Figure 17. When the efficiency of heat exchanger increases, COP and cooling capability are raised.

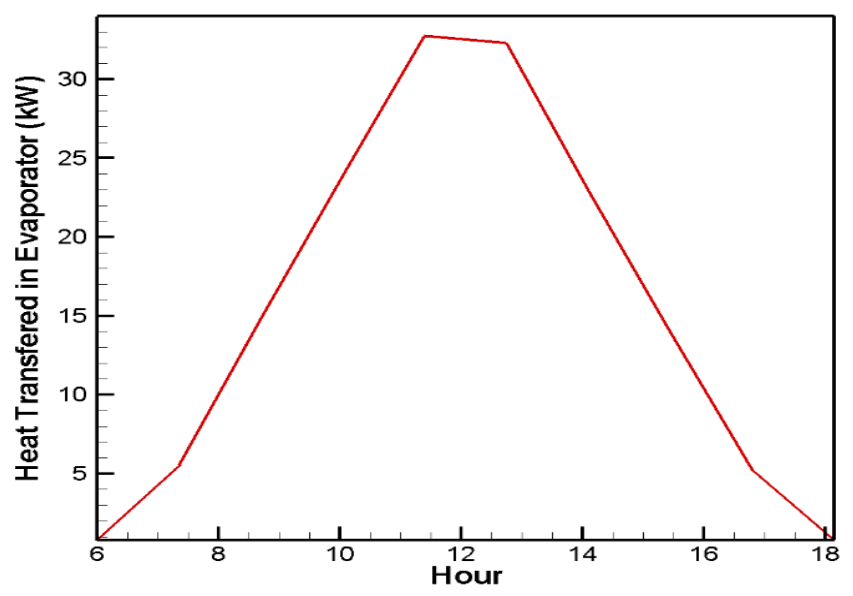

Figure 12. Cooling energy in evaporator versus time

Table 3. Cooling and heating load for different cities

\begin{tabular}{ccc}
\hline & Total cooling load (W) & Total heating load(W) \\
\hline Ankara & 7401 & 13008 \\
Abu Dhabi & 11683 & 3356 \\
Ad Dawah & 11456 & 3832 \\
Al Manama & 11183 & 3411 \\
Amman & 8739 & 6942 \\
Baghdad & 11609 & 7733 \\
Beirut & 8368 & 5550 \\
Cairo & 9698 & 4643 \\
Damascus & 8725 & 8828 \\
Karachi & 10404 & 4027 \\
Kuwait & 12608 & 6260 \\
Masqat & 11913 & 1692 \\
Riyadh & 11613 & 5497 \\
Nicosia & 9316 & 6976 \\
Tehran & 9750 & 9900 \\
\hline
\end{tabular}

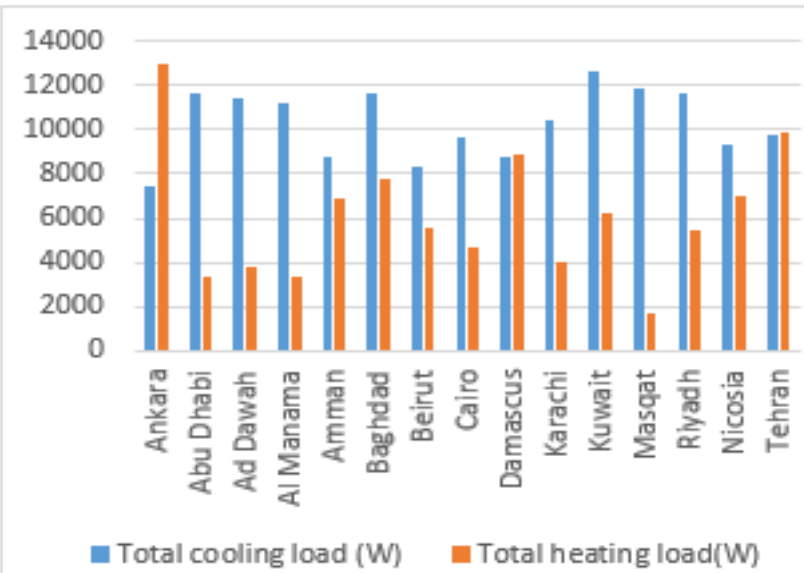

Figure 13. Cooling and heating load for different cities

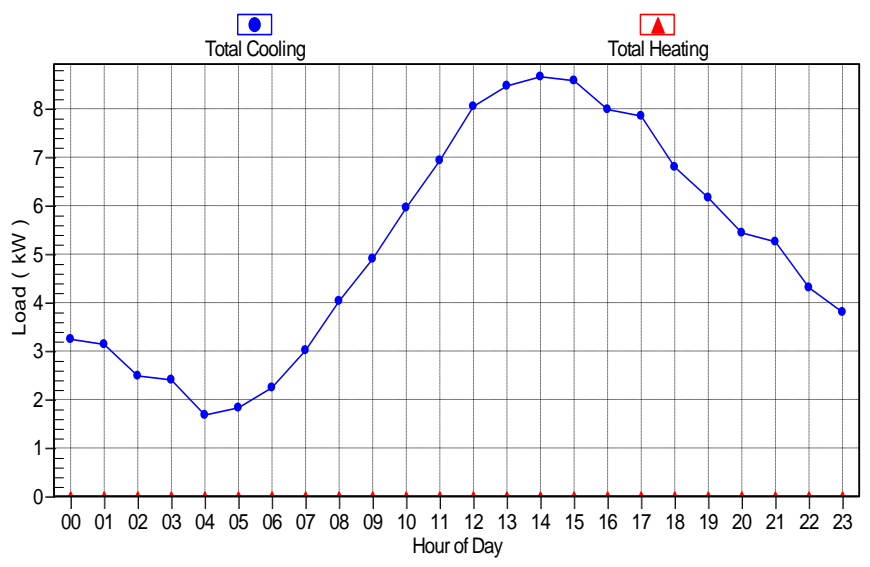

Figure 14. Total cooling and heating load variation in July for Damascus

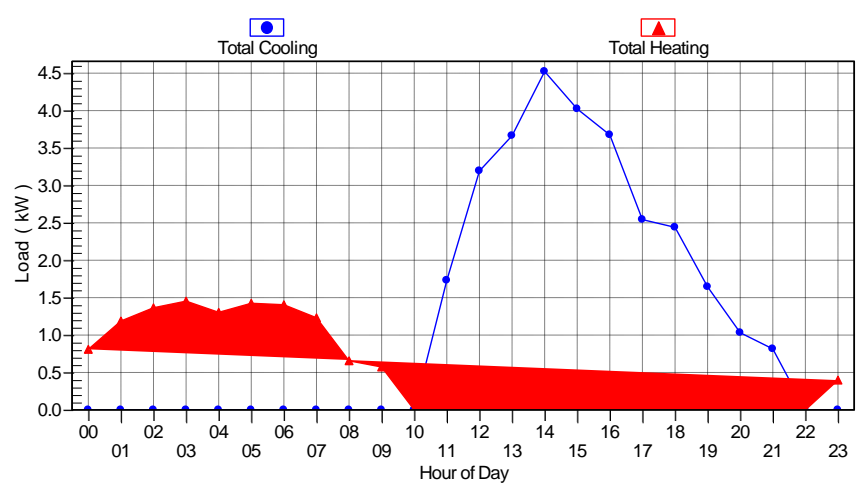

Figure 15. Total cooling and heating load variation in January for Baghdad

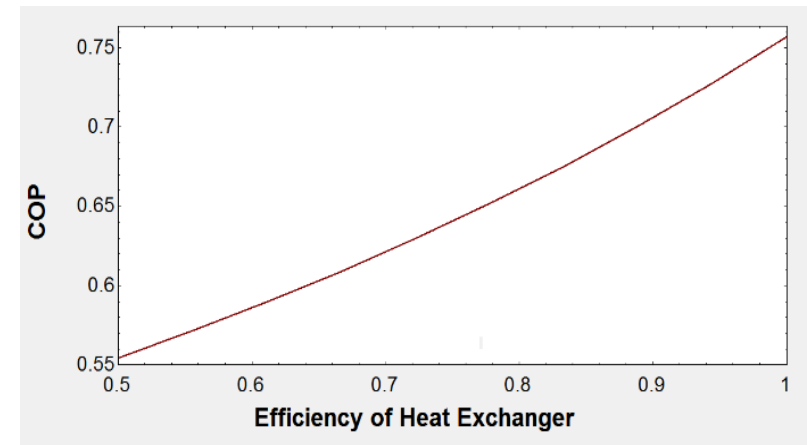

Figure 16. The coefficient of performance versus efficiency of heat exchanger

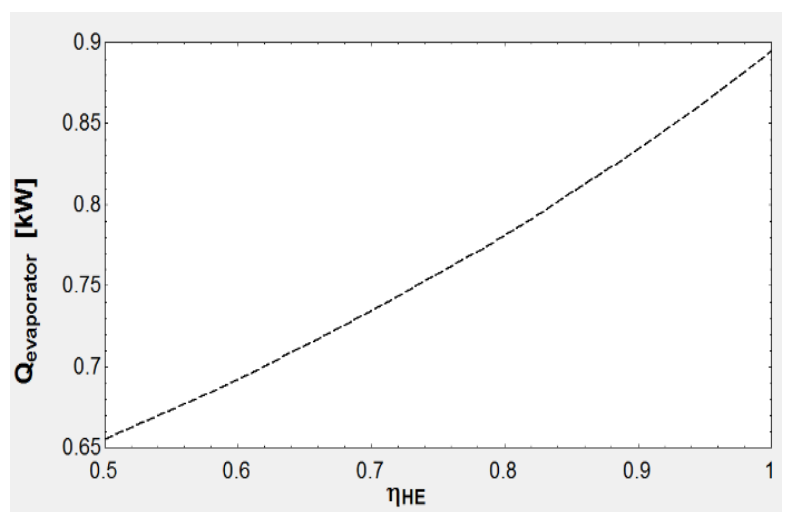

Figure 17. Cooling energy in evaporator versus efficiency of heat exchanger 


\section{CONCLUSION}

In this paper, the ammonia absorption refrigeration cycle (AARC) have been used to prepare cooling of capital cities in the Middle East. In this work, the cooling and heating load of an apartment in these cities have been calculated. Also the HVAC information of these cities such as design dry bulb temperature in summer and winter and solar heat gains (SHG) have been extracted from ASHREA handbook. The variation of temperature and cooling capacity in different month and different hours of a day is calculated and is shown in different figures. It is shown that cooling capacity depends on solar energy and solar energy changes during the day. The results show that the maximum SHG is five times the minimum SHG. As a results, cooling capacity change during the day. Fortunately, results show that the maximum cooling capacity is near the maximum cooling load of building. In the final part, the influence of the efficiency of the heat exchanger of AARC has been investigated. Outcomes show that the coefficient of performance and the cooling capacity increase when the efficiency of the heat exchanger of AARC rises. In this research, cooling load changes between $7401 \mathrm{~W}$ and $12500 \mathrm{~W}$ for Ankara and Kuwait.

\section{REFERENCES}

[1] Zhang X, Li H, Yang C. (2015). A novel solar absorption refrigeration system using the multi-stage heat storage method. Energy and Buildings 102: 157-62. https://doi.org/10.1016/j.enbuild.2015.05.011

[2] Yang L, Zhang X, Xu G. (2014). Thermal performance of a solar storage packed bed using spherical capsules filled with PCM having different melting points. Energy and Buildings 68: 639-46 https://doi.org/10.1016/j.enbuild.2013.09.045

[3] Tiwari D, Sherwani AF, Atheaya D, Arora A. (2017). Energy and exergy analysis of solar driven recuperated organic Rankine cycle using glazed reverse absorber conventional compound parabolic concentrator (GRACCPC) system. Solar Energy 155: 1431-42. https://doi.org/10.1016/j.solener.2017.08.001

[4] Paradis PL, Rousse DR, Lamarche L, Nesreddine H. (2017). A 2-D transient numerical heat transfer model of the solar absorber plate to improve $\mathrm{PV} / \mathrm{T}$ solar collector systems. Solar Energy 153: 366-78. https://doi.org/10.1016/j.solener.2017.05.058

[5] Lizarte R, Izquierdo M, Marcos JD, Palacios E. (2012). An innovative solar-driven directly air-cooled $\mathrm{LiBr}-\mathrm{H}_{2} \mathrm{O}$ absorption chiller prototype for residential use. Energy and Buildings 47: 1-11. https://doi.org/10.1016/j.enbuild.2011.11.011

[6] Abu-Ein SQ, Fayyad SM, Momani W, Al-Bousoul M. Performance analysis of solar powered absorption refrigeration system. Heat and Mass Transfer 46: 137. https://doi.org/10.1007/s00231-009-0538-1

[7] Eicker U, Pietruschka D. (2009). Design and performance of solar powered absorption cooling systems in office buildings. Energy and Buildings 41: 8191. https://doi.org/10.1016/j.enbuild.2008.07.015

[8] Adibi T, Kangarluei RA, Azar SKJ, Rossoli B. Investigating Effect of Intercooler on Performance and Efficiency of Brayton Cycle in Ideal and Non-ideal Condition. International Journal of Science, Engineering and Technology Research 6: 706-10.

[9] Mesmoudi K, Meguellati K, Bournet PE. (2017). Thermal analysis of greenhouses installed under semi arid climate. International Journal of Heat and Technology 35: 474-86. https://dx.doi.org/10.18280/ijht.350304

[10] Bataineh K, Taamneh Y. (2017). Performance analysis of stand-alone solar dish Stirling system for electricity generation. International Journal of Heat and Technology 35: 498-508. https://doi.org/10.1016/j.enconman.2016.10.024

[11] Fan YY, Feng JJ, Zhang XW. (2018). Analysis of random features of turbulent process in hydrocyclone based on computational fluid mechanics. Chemical Engineering Transactions 66: 427-432. http://dx.doi.org/10.3303/CET1866072

[12] Mustafa AR. (2018). Transient free convection MHD flow past an accelerated vertical plate with periodic temperature. Chemical Engineering Transactions 66: 331-336. http://dx.doi.org/10.3303/CET1866056

[13] Borgnakke C, Sonntag RE. (2015). Fundamentals of Thermodynamics. Don Fowley.

[14] (2016). American Society of Heating, Refrigerating and Air-Conditioning Engineers (ASHRAE) Handbook. 